\title{
PENGARUH KEPERCAYAAN, KEMUDAHAN DAN PERSEPSI RISIKO TERHADAP KEPUTUSAN PEMBELIAN JASA GOJEK DI KOTA SEMARANG YANG DIMEDIASI MINAT BELI SEBAGAI VARIABEL INTERVENING
}

\author{
Arif Reza Maharama \\ Noor Kholis \\ Universitas Islam Sultan Agung \\ arifreza.maharama@gmail.com
}

\begin{abstract}
Trust, Ease, Risk Perception and Buying Interest Consumers are one of the factors that are expected to improve Buying Service Decision Go-Jek online transportation in Semarang City. The formulation of the problem in this research is to know how the influence of trust, ease and perception of risk to purchasing decision of Go-Jek service in Semarang City, through consumer buying interest as intervening variable. The purpose of this study was to analyze the influence of trust, convenience, and risk perception of purchasing decision through consumer buying interest as intervening variable. The population in this study is the consumer of Go-Jek transportation users in Semarang City with a sample of 120 people using the formula Rao Purba. Methods of collecting documentation data and questionnaires, analytical methods of instrument test (validity test and reliability test), descriptive analysis of index answers per variable, classical assumption test and regresion path analysis, and using the test of sobel. The result of the research shows that there is positive and significant influence of trust, ease of buying decision of service with consumer buying interest as intervening variable, and there is negative and significant influence of risk perception to purchase decision with buying interest as intervening variable. The buying interest variable able to mediate the influence of trust, ease and perception of risk to purchase decision is evidenced by the test of sobel.
\end{abstract}

Keywords : Trust, Ease, Risk Perception, Buying Interest, Buying Decision

\section{PENDAHULUAN}

Di era globalisasi ini perkembangan teknologi dan informasi di dunia khususnya internet mengalami pertumbuhan yang sangat pesat. Internet menghubungkan satu orang dengan orang lainnya, menyediakan informasi, sebagai media entertainment, maupun sebagai sarana komunikasi. Oleh karena itu sebagian masyarakat memandang internet sebagai sesuatu yang wajib dipenuhi untuk menunjang kegiatan sehari-hari mereka. Menurut
(Laudon dan Laudon, 2007) setidaknya ada enam alasan mengapa teknologi internet begitu populer diantaranya adalah internet memiliki konektivitas dan jangkauan yang luas; mengurangi biaya komunikasi, biaya transaksi yang lebih rendah, dapat mengurangi biaya agensi, interaktif,

fleksibel, dan mudah; serta memiliki kemampuan untuk mendistribusikan pengetahuan secara cepat.

Fakta berbicara bahwa teknologi telah membuat berbagai perubahan dalam 


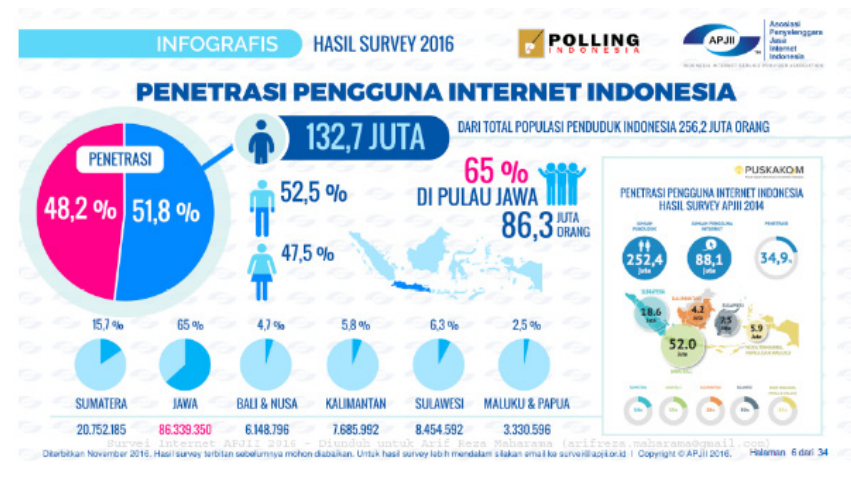

perkembangan bisnis, teknologi informasi banyak dimanfaatkan oleh para pelaku bisnis untuk mendukung kegiatan bisnisnya serta mendapatkan profit yang diinginkan. Sehingga lahirlah para kompetitor baru dengan berbagai inovasi yang unggul, sampai hadirnya model bisnis baru yang berbasis teknologi. Pada era globalisasi ini teknologi memegang peranan yang sangat vital, karena tidak hanya sebagai pelengkap dalam kegiatan bisnis, namun sebagai fundamental bisnis yang terus berkembang serta mampu berkompertensi menghadapi tantangan di dunia bisnis.

Berdasarkan survei yang dilakukan oleh Asosiasi Penyelenggara Jasa Internet Indonesia yang dilaksanakan selama tahun 2016 adalah sebanyak 132, 7 Juta masyarakat Indonesia telah menggunakan internet dari total keseluruhan populasi penduduk Indonesia sebanyak 256,2 juta jiwa.
Jumlah ini tentu meningkat dibanding dengan survei pada tahun 2014 yang hanya sebesar 88,1 juta jiwa pengguna Internet di Indonesia.

Dari grafik perilaku pengguna internet di Indonesia dapat kita ketahui bahwasannya perangkat yang dipakai dalam mengakses internet dengan menggunakan smartphone atau perangkat mobile mendapat porsi yang cukup besar sebesar $47,6 \%$ atau 63,1 juta jiwa, ini mendakan bahwa perilaku mengakses internet melalui ponsel berbeda dengan akses melalui komputer, mereka umumnya mengakses Internet untuk mengecek email, mengunjungi situs jejaring sosial, dan melakukan transaksi perbankan melalui layanan online. Hal tersebut mengidentifikasikan bahwa pengguna web berbasis mobile membuka peluang bisnis yang sangat menggairahkan. Kehadiran aplikasi GO-JEK beberapa tahun terakhir ini telah mengubah pola hidup masyarakat

PERILAKU PENGGUNA INTERNET INDONESIA

$\mathrm{C}=\mathrm{\square}$ PERANGKAT YANG DIPAKAI

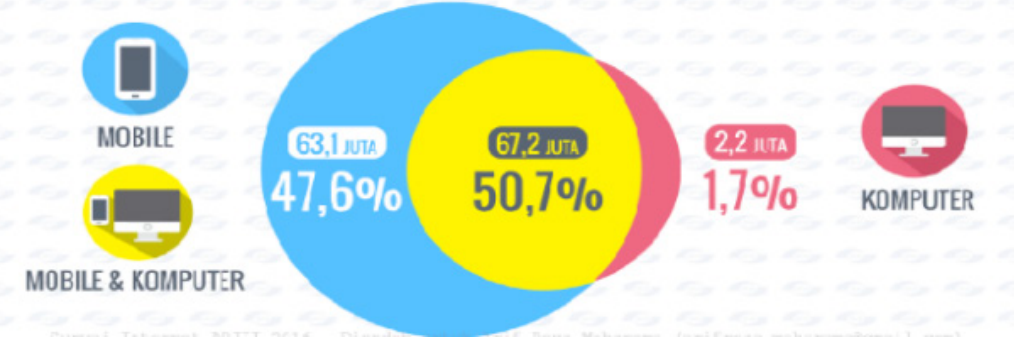

Gambar 2

Grafik Perilaku Pengguna Internet di Indonesia

Sumber: http://www.apjii.or.id 
Indonesia, karena berkat bisnis GO-JEK yang berkembang ke penyediaan berbagai jasa mulai dari transportasi hingga food delivery, kini saat ini pengguna aktif GOJEK telah mencapai angka 10 juta pengguna smartphone berbasis sistem aplikasi Android . Angka yang membuat kagum mengingat daerah operasional GO-JEK yang pada saat ini hanya mencakup beberapa kota besar yang ada di Indonesia.

Berbagai macam moda transportasi yang berbasis aplikasi online terus berkembang di Indonesia sehingga semakin menarik minat khalayak untuk menggunakannya, khususnya masyarakat yang berada di kotakota besar. Oleh karenanya kompetisi dalam merebut pasar transportasi berbasis aplikasi online pun mulai terasa, dimana bisnis ini mengandalkan kemudahan dan kepraktisan ini.

Kehadiran jasa transportasi melalui media online mendapat sambutan hangat bagi masyarakat. Transportasi yang merupakan kebutuhan kedua atau kebutuhan turunan dari kebutuhan ekonomi masyarakat. Peranan transportasi pada pembangunan wilayah secara menyeluruh telah membawa dampak yang luar biasa terutama sekali pada hubungan antar berbagai wilayah (aksesbilitas). Kehadiran jasa transportasi berbasis aplikasi online mendapat sambutan yang hangat bagi masyarakat. Transportasi yang merupakan kebutuhan kedua atau kebutuhan turunan dari kebutuhan ekonomi masyarakat. Peranan transportasi pada pembangunan wilayah secara menyeluruh telah membawa dampak yang luar biasa terutama sekali pada hubungan antar berbagai wilayah (aksesbilitas), namun permasalahan di bidang transportasi tidak henti-hentinya menjadi perhatian vital bagi masyarakat dan pemerintah Indonesia, permasalahan tersebut adalah kemacetan yang terjadi di hampir wilayah perkotaan baik di kota-kota besar yang ada di Indonesia, bahkan tidak menutup kemungkinan hingga saat ini mulai merambah daerah pinggiran dan kepedesaan. Berdasarkan data yang dihimpun oleh Badan Pusat Statistik, laju pertumbuhan jalan sejak tahun 2006-2012 hanya sekitar $287.193 \mathrm{~km}$ atau mengalami pertambahan jalan sekitar $11.046 \mathrm{~km}$ pertahun. Sementara laju pertumbuhan kendaraan bermotor sejak tahun 1987-2012 mencapai 86,4 juta unit kendaraan (sekitar $93 \%$ ) atau bertambah sekitar 3,3 juta unit kendaraan setiap tahunnya.

Kemacetan terjadi karena dimensi panjang dan lebar jalan sudah tidak mampu lagi menampung volume kendaraan, terlebih kendaraan pribadi yang jumlahnya terus mengalami peningkatan tiap tahunnya. Moda transportasi darat seperti bus kota, angkutan kota ataupun angkutan lainnya belum mampu menggerakkan pemilik kendaraan pribadi berpindah moda transportasi. Permasalah itu antara lain masalah kenyamanan yang dimiliki moda transportasi tersebut sangatlah rendah, Khususnya bus kota dan angkutan kota yang selalu menunggu penumpang penuh dan memakan waktu yang tidak sedikit serta tidak jarang berhenti di tempat-tempat yang dilarang untuk parkir sehingga menimbulkan kemacetan yang cukup parah, banyaknya pengamen dan pedagang asongan yang datang sering berganti membuat penumpang merasa kurang nyaman dalam menggunakan transportasi umum. Fenomena supir angkutan umuum yang mengendarai secara ugal-ugalan, kondisi kendaraan yang tidak dapat dikatakan layak beroperasi serta fasilitas yang tidak terawat dan berbagai macam kasus kejahatan yang terjadi di moda transportasi umum membuat masyarakat kehilangan akan kepercayaan akan penggunaan moda transportasi umum.

Bisnis transportasi berbasis aplikasi online merupakan suatu inovasi layanan yang memanfaatkan teknologi mutakhir. Inovasi ini dengan cepat menarik hati banyak orang, khususnya para masyarakat yang memanfaatkan layanan tranportasi taksi dan ojek. Tak heran, apabila model bisnis seperti ini selalu mengalami perkembangan di tengah pro dan kontra. Patut diakui walaupun 


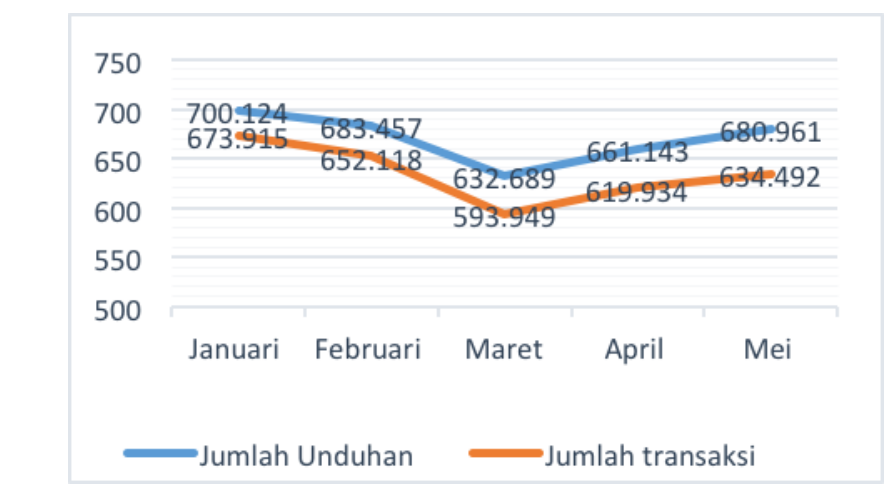

\section{Gambar 3 \\ Kurva unduhan aplikasi go-jek \\ dan Transaksi pelanggan Go-Jek selama Januari-Mei 2017 \\ Sumber : PT Go-Jek Indonesia}

dihiasi oleh berbagai macam polemik, bisnis seperti ini menyajikan banyak manfaat bagi banyak pihak mulai dari user, driver hingga pebisnis itu sendiri.

Persaingan di bisnis ini sangat ketat maka perusahaan berlomba-lomba untuk menarik minat konsumen dengan mengutamakan pelayanan prima dari pihak perusahaan, sehingga konsumen akan merasakan kepuasan dan bisa mendorong orang tersebut untuk melakukan keputusan pembelian.Namun tidak seluruhnya sesuai keinginan dengan menggunakan sistem jasa transportasi online ini. Ada saja kekurangan yang ditimbulkan oleh sistem transportasi berbasis online ini salahsatunya dari segi pelayanan meski pihak perusahaan mengedepankan pelayanan yang lebih baik, tetapi kenyataannya bahwa konsumen ada saja yang mengeluhkan pelayanan terhadap penyedia jasa transportasi online tsb ini baik itu dari segi aplikasi yang belum semua masyarakat dapat mengoperasikannya dengan mudah maupun dari segi pelayanan drivernya yang terkadang tidak mematuhi aturan yang telah menjadi standarisasi dari pihak perusahaan penyedia jasa tersebut.

Jasa transportasi berbasis aplikasi online banyak dipilih oleh publik dikarenakan proses order yang mudah, perhitungan cost lebih transparan, dan service yang lebih memuaskan, dikarenakan pelanggan tidak perlu keluar rumah untuk memesan jasa ini, cukup bermodalkan akses internet dan perangkat smartphone. Aplikasi ini tidak hanya melayani jasa untuk mengantarkan penumpang ke berbagai tempat tujuan saja, namun jasa transportasi online juga menambahkan berbagai macam opsi berupa servis tambahan sebagai kurir, yaitu bisa sebagai kurir pengantar barang, membelikan makanan dan minuman di berbagai outlate yang telah menjalin kerjasama dengan bisnis transportasi online serta berbagai keperluan lain sampai dengan layanan jasa kebersihan profesional tiket untuk membersihkan kos, kantor dan rumah. Untuk pengguna mereka menemukan sebuah jasa tranportasi yang mempunyai keunggulan dikarenakan adanya kemudahan, lebih murah, lebih nyaman, serta mampu dikatan aman juga.

Gambar 3 merupakan kurva transaksi Pelanggan Go-Jek dengan membandingkan pada tingkat unduhan aplikasi gojek. Terdapat gap atau rentang yang sangat tinggi antara tingkat Unduhan konsumen dengan konsumen yang melakukan transaksi penggunaan jasa transportasi online Gojek Tersebut..

Tingginya gap antara unduhan aplikasi dengan jumlah konsumen yang melakukan transaksi jasa transportasi online dapat diperkirakan disebabkan oleh beberapa fakor kemungkinan yang tebesar seperti berikut :

a.) Pelayanan dari mitra Go-jek tidak 
memberikan kepercayaan terhadap konsumen. b.) Tidak mengerti bagaimana mengoperasikan aplikasi go-jek tersebut, terkait dengan kemudahan penggunaanya. c.) Kompetitor memberikan resiko yang rendah terhadap konsumen sehingga konsumen Go-jek berpindah.

Faktor-faktor tersebut merupukan indikator bagaimana konsumen merasa tidak puas dengan Go-jek, Upaya untuk memenuhi kepuasan pada diri konsumen dalam menggunakan jasa transportasi Gojek yaitu dengan memberikan pelayanan secara online dan pelayanan secara langsung dari pihak yang bermitra dengan Go-jek tersebut secara resmi. Ini menjadi perhatian penting bagi perusahaan trasnportasi online untuk memberikan kepuasan kepada konsumen. Dampak dari kepuasan yang timbul pada diri konsumen juga dapat membuat konsumen akan tetap loyal terhadap jasa trasnportasi online tersebut.

\section{KAJIAN PUSTAKA}

\section{Keputusan Pembelian}

Menurut Schiffman dan Kanuk (2007) keputusan adalah seleksi terhadap dua pilihan atau lebih. Sehingga dengan kata lain, pilihan alternatif harus tersedia ketika seseorang mengambil keputusan.Menurut Kotler dan Amstrong (2001:226) Keputusan pembelian adalah tahap dalam proses pengambilan keputusan pembeli dimana komsumen benar-benar membeli produk. Menurut Kotler dan Amstrong (2001) bahwa proses melakukan keputusan pembelian terdiri dari lima tahap, diantaranya adalah; pengenalan kebutuhan, pencarian informasi, evaluasi berbagai macam alternatif keputusan pembelian, perilaku pasca pembelian.

Sedangkan Indikator Keputusan Pembelian yaitu; kemantapan membeli, pertimbangan dalam membeli, kesesuaian atribut dengan keinginan dan kebutuhan.

\section{Minat Beli}

Minat beli menurut Kotler (2005) adalah sesuatu yang timbul setelah menerima rangsangan dari produk yang dilihatnya, dari sana timbul ketertarikan untuk membeli agar dapat memilikinya. Minat beli konsumen akan timbul dengan sendirinya jika konsumen sudah merasa tertarik atau memberikan respon yang positif terhadap apa yang ditawarkan oleh si penjual. Minat beli juga merupakan instruksi diri konsumen untuk melakukan pembelian atas suatu produk, melakukan perencanaan, mengambil tindakan-tindakan yang relevan seperti mengusulkan, merekomendasikan, memilih dan akhirnya mengambil keputusan untuk melakukan pembelian Rossiter dan Percy (1997). Perilaku minat untuk membeli adalah hasil dari proses evaluasi terhadap merek. Tahapan terakhir dari pengambilan keputusan secara kompleks termasuk membeli merek yang diinginkan, mengevaluasi merek tersebut pada saat dikonsumsi dan menyimpan informasi ini untuk digunakan di masa yang akan datang Sylvana, (2006).

Indikator minat beli antara lain: Minat eksploratif (mencari informasi), Minat transaksional (kecendurungan untuk melakukan pembelian), Minat preferensial (menjadikan yang utama)

\section{Kepercayaan}

Mowen (2002) menyatakan bahwa kepercayaan adalah semua pengetahuan yang dimiliki oleh konsumen dan semua kesimpulan yang dibuat oleh konsumen tentang objek, atribut dan manfaatnya. Maksud dari objek disini adalah berupa produk atau jasa, orang, perusahaan dan segala sesuatu dimana seseorang memiliki kepercayaan dan sikap.

Kepercayaan dapat diwujudkan apabila sebuah produk atau jasa telah memenuhi keinginan dan kebutuhan pelanggan, dimana konsumen akan puas terhadap produk tersebut. Kepercayaan akan 
timbul apabila konsumen telah merasakan kepuasan karena telah mengkonsumsi atau menggunakan produk dengan merek tertentu. Konsumen yang merasa nyaman dan percaya karena sebuah brand, tidak akan mudah meninggalkan atau mengganti brand tersebut dengan produk merek lain.

Indikator kepercayaan antara lain: Kemampuan, Kebaikan hati, Integritas

\section{Kemudahan}

Dengan berjalannya waktu animo masyarakat dalam menggunakan ponsel pintar sangat antusias, oleh karena itu munculah berbagai macam aplikasi-aplikasi dengan berbagai fungsi dan fitur yang berbeda. Hal ini dimanfaatkan sebagian developer lokal untuk mendesain dan mengembangkan aplikasi yang menjadikan kemudahan dan kepraktisan bagi para penggunanya. Kemudahan merupakan salah satu hal yang sangat ditinjau dalam melakukan keputusan penggunaan jasa transportasi online. Menurut Davis (1989: 320), Kemudahan (perceived ease of use) diartikan sebagai fase dimana user meyakini bahwa penggunaan teknologi adalah hal yang mudah dan tidak memerlukan usaha keras dari user itu sendiri. Pendapat ini meliputi kejelasan sasaran penggunaan teknologi dan kemudahan penggunaan sistem untuk tujuan sesuai dengan keinginan user.

Indikator Kemudahan

Menurut Davis (1989), indikator kemudahan terdiri dari: 1.mudah untuk dipelajari

2.dapat dikendalikan

3.mudah untuk digunakan

\section{Persepsi Resiko}

Dalam penelitian yang dilakukan oleh Julianto (2012) dijelaskan bahwa persepsi risiko adalah risiko yang dipersepsikan oleh konsumen terhadap suatu produk atau jasa yang berhubungan dengan segala ketidakpastian dan segala akibantya terhadap konsumen. Semakin mampu konsumen menanggulangi ketidakpastian serta konsekuensi dari produk atau jasa tersebut maka akan semakin rendah persepsi risiko produk tersebut di benak pikiran konsumen. Sebaliknya, apabila konsumen tidak mampu mengantisipasi ketidakpastian serta konsekuensi yang dihasilkan oleh produk dan jasa tersebut, maka akan berakibat semakin tinggi persepsi risiko produk tersebut di pemikiran para konsumen. Indikator Persepsi Resiko : resiko pencurian, resiko terjadi kecelakaan, resiko penipuan

\section{Kerangka Pemikiran Teoritis dan Perumusan Hipotesis}

Berdasarkan landasan teori yang telah dijelaskan dan hasil penelitian terdahulu beserta permasalahan yang telah diambil, maka variabel-variabel dalam mempengaruhi keputusan pembelian jasa gojek adalah: kepercayaan, kemudahan dan resiko, serta minat beli sebagai variabel intervening

H1: Terdapat pengaruh positif antara kepercayaan terhadap minat beli

H2: Terdapat pengaruh positif antara kemudahan terhadap minat beli

H3: Terdapat pengaruh negatif antara risiko terhadap minat beli

H4: Terdapat pengaruh positif antara kepercayaan terhadap keputusan pembelian

H5: Terdapat pengaruh positif antara kemudahan terhadap keputusan pembelian

H6: Terdapat pengaruh negatif antara risiko terhadap keputusan pembelian jasa transportasi online

H7: Terdapat pengaruh positif antara minat beli terhadap keputusan pembelian.

\section{Metodelogi Penelitian}

Berdasarkan tujuan penelitian yang telah dijelaskan di bab sebelumnya, maka jenis penelitian yang digunakan adalah Explanatory research. Penelitian ini 


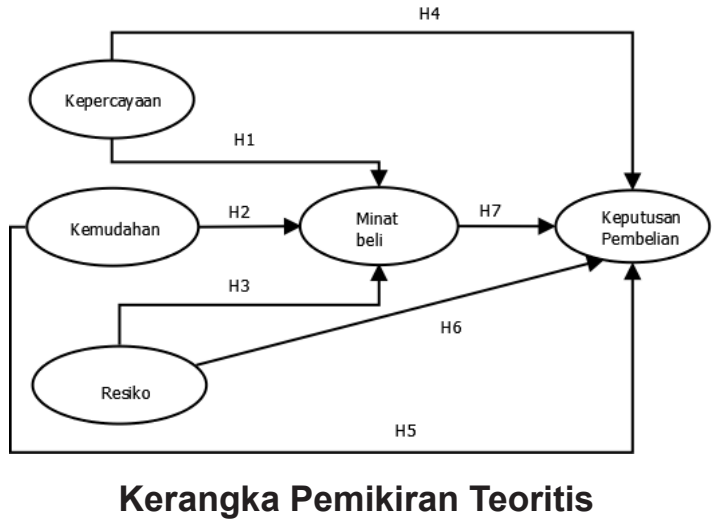

merupakan penelitian yang menjelaskan hubungan antara variabel-variabel yang bersifat deksripsi, namun hubungan tersebut terletak di antara variabel sehingga diharapkan dalam penelitian ini pengujian hipotesis tidak hanya berhenti pada tahap melukiskan saja tetapi peneliti dapat mengambil suatu kesimpulan yang berlaku pada masalah yang diteliti (Sugiyono,2005)

Populasi penelitian ini adalah para konsumen yang telah menggunakan jasa transportasi berbasis aplikasi online GOJEK di Kota Semarang. Terkait dengan populasi yang jumlahnya sangat banyak dan tidak dapat diketahui jumlah secara pasti, maka diambilah beberapa sampel untuk mewakili populasi tersebut. Berdasarkan alasan tersebut jumlah sampel yang dilakukan oleh peneliti mengacu pada rumus Rao Purba (1996) dalam Yaufi Adriyano (2014:72) apabila sampel berukuran besar dan jumlahnya tidak diketahui, maka digunakanlah rumus sebagai berikut:

$$
n=\frac{Z^{2}}{4(\text { Moe })^{2}}
$$

Keterangan

$\mathrm{n} \quad$ : Jumlah Sampel

Z : Tingkat distribusi normal pada taraf signifikan $5 \%=1,96$

Moe : Margin of error atau kesalahan maksimal yang bisa ditoleransi Disini ditetapkan $10 \%$ atau 0,10

Dengan data tersebut maka dapat dilihat ukuran sampel minimal yang harus dicapai dalam penelitian ini dengan menggunakan perhitungan sebagai berikut:

$$
n=\frac{1,96^{2}}{4(0,10)^{2}}
$$

$\mathrm{N}=96,4$ dibulatkan menjadi 97

Berdasarkan rumus tersebut maka jumlah minimal sampel dalam penelitian ini sampel adalah berjumlah 100 responden. Dan dalam penelitian ini mengambil sampel sebanyak 120 responden pengguna jasa GO-JEK di Kota Semarang.

Dalam hal ini, penulis menggunakan pendekatan purposive sampling, hal ini disebabkan karena penulis tidak memberikan peluang yang sama terhadap konsumen GO-JEK Kota Semarang untuk dijadikan sampel. Dalam memilih responden yang tepat maka ditetapkan berbagai syarat dan karakteristik sebagai berikut:

1) Responden minimal berusia 17 tahun, dengan alasan responden dapat memberikan jawaban yang kritis dan dapat dipertanggung jawabkan

2)Responden telah menggunakan jasa tranportasi berbasis aplikasi online GO-JEK, minimal sebanyak 3 kali karena pengalaman responden dalam menggunakan jasa tersebut sangat dibutuhkan khususnya untuk menjawab berbagai pertanyaan mengenai kepercayaan, kemudahan, risiko, minat beli dan keputusan pembelian jasa transportasi online GO-JEK. 
Tabel 1. Analisis Regresi Pengaruh

Kepercayaan, Kemudahan dan Persepsi Resiko

terhadap Minat Beli

Coefficients $^{\mathrm{s}}$

\begin{tabular}{|c|c|c|c|c|c|c|}
\hline \multirow[b]{2}{*}{ Made } & & \multicolumn{2}{|c|}{ Unstandardized Coefficients } & \multirow{2}{*}{$\begin{array}{c}\text { Standardized } \\
\text { Coefficients } \\
\text { Beta }\end{array}$} & \multirow[b]{2}{*}{ t } & \multirow[b]{2}{*}{ Siq. } \\
\hline & & B & Std. Error & & & \\
\hline \multirow[t]{4}{*}{1} & (Constant) & 5.573 & .892 & & 6.251 & .000 \\
\hline & Kepercayaan & .314 & .100 & .358 & 3.126 & .002 \\
\hline & Kemudahan & .315 & .118 & .329 & 2.662 & .009 \\
\hline & Persepsi Resiko & -.261 & .091 & -249 & -2.858 & .005 \\
\hline
\end{tabular}

a. Dependent Variable: Minat Beli

HASIL PENELITIAN DAN PEMBAHASAN

1. Analisis Pengaruh Kepercayaan,

Kemudahan, Persepsi Resiko

terhadap Minat Beli Konsumen.

Hasil analisis regresi pengaruh kepercayaan, kemudahan dan persepsi resiko terhadap minat beli konsumen dapat dilihat pada tabel 1 .

Berdasarkan tabel 1 dapat diketahui persamaan regresinya sebagai berikut:

$$
\begin{aligned}
& Y 1=b 1 \times 1+b 2 \times 2+b 3 \times 3 \\
& Y 1=0,358 \times 1+0,329 \times 2-0,249 \times 3
\end{aligned}
$$

\section{Analisis Pengaruh Kepercayaan,}

Kemudahan, Persepsi Resiko, Minat beli terhadap Keputusan Pembelian

Hasil analisis regresi pengaruh kepercayaan, kemudahan,persepsi resiko dan minat beli terhadap keputusan pembelian konsumen dapat dilihat pada tabel 2 .

Berdasarkan tabel 2 dapat diketahui persamaanya sebagai berikut.

$Y 2=b 1 X 1+b 2 \times 2+b 3 X 3+b 4 Y 2$
$Y 2=0,237 X 1+0,365 X 2-0,262 X 3$

\section{Pengujian Hipotesis}

a. Pengaruh Variabel Kepercayaan Terhadap Minat Beli

Dari hasil perhitungan diperoleh nilai $\mathrm{t}$ hitung adalah 3.126 dengan menggunakan taraf signifikan sebesar 0.05 yang diperoleh dari $\mathrm{t}$ tabel sebesar 1.658 yang berarti menunjukkan bahwa nilai $\mathrm{t}$ hitung lebih besar dibandingkan $\mathrm{t}$ tabel yaitu $3.126>$ 1.658. Serta nilai signifikansi hitung $0.00<$ 0.05 . Dengan demikian dapat disimpulkan bahwa Ho ditolak dan Ha diterima, sehingga hipotesis yang menyatakan dugaan adanya pengaruh positif kepercayaan terhadap minat beli layanan GO-JEK diterima.

b. Pengaruh Variabel Kemudahan Terhadap Minat Beli

Dari hasil perhitungan diperoleh nilai $t$ hitung adalah 2.662 dengan menggunakan taraf signifikan sebesar 0.05 yang diperoleh dari $t$ tabel sebesar 1.658 yang berarti menunjukkan bahwa nilai $t$ hitung lebih besar dibandingkan $\mathrm{t}$ tabel yaitu $2.662>$ 1.658. Serta nilai signifikansi hitung $0.002<$

Tabel 2. Analisis Regresi Pengaruh Kepercayaan, Kemudahan, Persepsi Resiko, Minat Beli terhadap Keputusan Pembelian

\begin{tabular}{|c|c|c|c|c|c|c|}
\hline \multirow[b]{2}{*}{ Mad } & & \multicolumn{2}{|c|}{ Unstandardized Coefficients } & \multirow{2}{*}{$\begin{array}{c}\begin{array}{c}\text { Standardized } \\
\text { Coefficients }\end{array} \\
\text { Beta }\end{array}$} & \multirow[b]{2}{*}{$t$} & \multirow[b]{2}{*}{ Sig. } \\
\hline & & B & Std. Error & & & \\
\hline \multirow[t]{5}{*}{1} & (Constant) & 4.792 & .903 & & 5.304 & .000 \\
\hline & Kepercayaan & .213 & .092 & .237 & 2.324 & .022 \\
\hline & Kemudahan & .358 & .107 & .365 & 3.351 & .001 \\
\hline & Persepsi Resiko & -.282 & .083 & -.262 & -3.411 & .001 \\
\hline & Minat Beli & .311 & .081 & .303 & 3.825 & .000 \\
\hline
\end{tabular}

Coefficients ${ }^{\mathrm{s}}$

a. Dependent Variable: Keputusan Pembelian 
0.05. Dengan demikian dapat disimpulkan bahwa Ho ditolak dan Ha diterima, sehingga hipotesis yang menyatakan dugaan adanya pengaruh positif kemudahan terhadap minat beli layanan GO-JEK diterima.

c. Pengaruh Variabel Persepsi Resiko Terhadap Minat Beli

Dari hasil perhitungan diperoleh nilai t hitung adalah -2.558 yang diabsolutkan menjadi 2.558 dengan menggunakan taraf signifikan sebesar 0.05 yang diperoleh dari $\mathrm{t}$ tabel sebesar 1.658 yang berarti menunjukkan bahwa nilai $t$ hitung lebih besar dibandingkan $t$ tabel yaitu $2.558>$ 1.658. Serta nilai signifikansi hitung $0.005<$ 0.05 . Dengan demikian dapat disimpulkan bahwa Ho ditolak dan Ha diterima, sehingga hipotesis yang menyatakan dugaan adanya pengaruh negatif persepsi resiko terhadap minat beli layanan GO-JEK diterima.

d. Pengaruh Variabel Kepercayaan Terhadap Keputusan Pembelian

Dari hasil perhitungan diperoleh nilai $t$ hitung adalah 2.324 dengan menggunakan taraf signifikan sebesar 0.05 yang diperoleh dari $\mathrm{t}$ tabel sebesar 1.658 yang berarti menunjukkan bahwa nilai $\mathrm{t}$ hitung lebih besar dibandingkan $\mathrm{t}$ tabel yaitu $2.324>$ 1.658. Serta nilai signifikansi hitung $0.000<$ 0.05 . Dengan demikian dapat disimpulkan bahwa Ho ditolak dan Ha diterima, sehingga hipotesis yang menyatakan dugaan adanya pengaruh positif kepercayaan terhadap keputusan pembelian layanan GO-JEK diterima.

e. Pengaruh Variabel Kemudahan Terhadap Keputusan Pembelian

Dari hasil perhitungan diperoleh nilai $\mathrm{t}$ hitung adalah 3.351 dengan menggunakan taraf signifikan sebesar 0.05 yang diperoleh dari $t$ tabel sebesar 1.658 yang berarti menunjukkan bahwa nilai $t$ hitung lebih besar dibandingkan $\mathrm{t}$ tabel yaitu $3.351>$ 1.658. Serta nilai signifikansi hitung $0.022<$ 0.05 . Dengan demikian dapat disimpulkan bahwa Ho ditolak dan Ha diterima, sehingga hipotesis yang menyatakan dugaan adanya pengaruh positif kemudahan terhadap keputusan pembelian layanan GO-JEK diterima.

f. Pengaruh Variabel Persepsi Resiko Terhadap Keputusan Pembelian

Dari hasil perhitungan diperoleh nilai t hitung adalah -3.411 yang diabsolutkan menjadi 3.411 dengan menggunakan taraf signifikan sebesar 0.05 yang diperoleh dari $t$ tabel sebesar 1.658 yang berarti menunjukkan bahwa nilai t hitung lebih besar dibandingkan $t$ tabel yaitu 3.441 .658 . Serta nilai signifikansi hitung $0.001<0.05$. Dengan demikian dapat disimpulkan bahwa Ho ditolak dan Ha diterima, sehingga hipotesis yang menyatakan dugaan adanya pengaruh negatif persepsi resiko terhadap keputusan pembelian layanan GO-JEK diterima.

g. Pengaruh Variabel Minat Beli Terhadap Keputusan Pembelian

Dari hasil perhitungan diperoleh nilai $t$ hitung adalah 3.825 dengan menggunakan taraf signifikan sebesar 0.05 yang diperoleh dari $\mathrm{t}$ tabel sebesar 1.658 yang berarti menunjukkan bahwa nilai $t$ hitung lebih besar dibandingkan $\mathrm{t}$ tabel yaitu $3.825>$ 1.658. Serta nilai signifikansi hitung $0.000<$ 0.05 . Dengan demikian dapat disimpulkan bahwa Ho ditolak dan Ha diterima, sehingga hipotesis yang menyatakan dugaan adanya pengaruh positif minat beli terhadap keputusan pembelian layanan GO-JEK diterima.

\section{Uji Mediasi atau intervening}

a. Pengaruh kepercayaan terhadap keputusan pembelian melalui minat beli konsumen

Hasil uji sobel variabel kepercayaan terhadap keputusan pembelian melalui minat beli

Berdasarkan hasil perhitungan nilai $\mathrm{t}$ hitung menunjukkan 2.586 dimana hasil tersebut lebih besar dari $t$ tabel dengan tingkat signifikasi 0.05 sebesar 1.658 serta nilai $p$ value 0.009 lebih kecil dari 0.05 maka dapat disimpulkan variabel minat beli (Y1) adalah variabel intervening dan terbukti 
layak

b. Pengaruh kemudahan terhadap keputusan pembelian melalui minat beli konsumen

\section{Hasil uji sobel variabel persepsi resiko terhadap keputusan pembelian melalui minat beli.}

Berdasarkan hasil perhitungan $t$ hitung menunjukkan -2.286 diabsolutkan menjadi 2.286 dimana hasil tersebut lebih besar dari t hitung dengan signifikasi 0.05 yaitu sebesar 1.658 serta nilai $p$ value sebesar 0.02 lebih kecil dari 0.05 maka dapat disimpulkan variabel minat beli (Y1) adalah variabel intervening dan terbukti layak. Hasil t hitung negatif menunjukkan bahwa persepsi resiko mempunyai hubungan berlawanan arah terhadap keputusan pembelian melalui minat beli.

\section{SIMPULAN}

Berdasarkan penelitian yang telah dilakukan, maka dapat dibuat kesimpulan sebagai berikut :

Kepercayaan berpengaruh positif dan signifikan terhadap minat beli konsumen dan keputusan pembelian, dan terbukti bahwa minat beli mampu berperan sebagai variabel intervening

Kepercayaan berpengaruh positif dan signifikan terhadap minat beli konsumen dan keputusan pembelian, dan terbukti bahwa minat beli mampu berperan sebagai variabel intervening

Persepsi resiko berpengaruh negatif dan signifikan terhadap minat beli konsumen dan keputusan pembelian, dan terbukti bahwa minat beli mampu berperan sebagai variabel intervening

Berdasarkan kesimpulan yang telah dikemukakan, maka diberikan beberapa saran yang diharapkan dapat meningkatkan keputusan pembelian. Adapun saran-saran sebagai berikut:

Responden menilai bahwa mudah dalam menggunakan jasa layanan GOJEK, namun ada yang perlu diperhatikan bagi perusahaan terhadap kemudahan dalam mengendalikan aplikasi tersebut di berbagai smartphone terkait dengan sistem operasi yang belum dapat digunakan seluruhnya serta penggunaan bahasa Indonesia yang minim di tampilan menu oleh karena itu pihak developer aplikasi GO-JEK perlu mengupdate aplikasi tersebut untuk kemudahan para konsumen GO-JEK dan menambah menu bahasa indonesia di tampilan aplikasi sehingga dapat dipakai di smartphone di semua sistem operasi Android dan los serta Microsoft sesuai dengan perkembangan teknologi. agar semua khalayak dapat menikmati aplikasi tersebut.

Responden memiki minat beli yang tinggi dalam menggunakan jasa go-jek, namun ada yang perlu diperhatikan dalam menjadikan gojek sebagai pilihan utama para konsumen. Ada beberapa yang harus di lakukan oleh perusahaan harus yaitu menambah jumlah armada dan coverage area agar konsumen dapat dengan mudah mendapatkan layanan GO-JEK, melakukan promosi dengan menggandeng beberapa media di Kota Semarang agar masyarakat khususnya di pinggiran kota mengetahui keberadaan Go-jek.

Responden memiliki kepercayaan yang tinggi terhadap jasa layanan ojek online GO-JEK, maka diharapkan pihak GOJEK tetap berusaha mempertahankan dan meningkatkan persepsi kepercayaan yang berhubungan langsung dengan konsumen melalui kejelasan informasi tarif dan jarak tempuh, cara yang dapat dilakukan adalah dengan melakukan perbaikan terhadap aplikasi tersebut dan mencocokkan dengan kordinat GPS terkait akan

akurasi jarak yang berdampak pada besarnya tarif layanan GO-JEK.

Responden menilai bahwa cukup terdapat resiko dalam menggunakan jasa layanan GO-JEK, namun ada yang perlu dipershatikan adalah aplikasi gojek rawan terjadi pencurian data konsumen untuk itu perusahaan juga memberikan kesadaran 
kepada konsumen bahwa penggunaan jasa layanan gojek juga memiliki resiko sehingga terjadi pemahaman pada konsumen akan resiko dengan menggunakan jasa tersebut. Pihak GO-JEK juga harus meningkatkan keamanan di dalam aplikasi dengan menggandeng pihak IT dalam menjaga database konsumen di server yang dapat menjamin data pribadi konsumen agar tidak bocor kepada pihak yang tidak bertanggung jawab. Pemberian pasword akses kepada konsumen gojek diharapkan dapat menimalisir penyalahgunaan akun konsumen, serta pelayanan pengaduan 24 jam sangat diperlukan dalam mengatasi keluhan konsumen apabila terjadi kebocoran data konsumen.

\section{DAFTAR PUSTAKA}

Davis, Fred D. (1989). Peerceived Usefulness, Perceived Ease of Use, and User Acceptance of Information Technology. MIS Quarterly, 13 (3) : 319-340.

Gefen, D., Rao, V.S. \& Tractinsky, N. (2003). The Conceptualization of Trust, Risk and Their Relationship in Electronic Commerce: The Need For Clarification. Proceedings of the 26th Hawai International Conference on System Sciences.

Julianto, Steven. (2012). Pengaruh Perceived Risk Dan Customer Satisfaction Terhadap Purchase Intention Dan Intention To Revisit Pada Gramedia Online Surabaya. Kajian IImiah Mahasiswa Manajemen 1 (1) : 46-50.

Kotler, Philip dan Armstrong, Gary. (2001). Prinsip- Prinsip Pemasaran, Jakarta: Erlangga.

Kotler, Philip \& Gary Armstrong. (2004). "Principles of Marketing". 10th Ed. NewJersey: Pearson Prentice Hall.

Laudon, Kenneth C., \& Laudon, Jane P. (2007). Sistem Informasi Manajemen Edisi Ke-10. Terjemahan Christian Sungkono dan Machmudin Eka P. Jakarta: Salemba Empat.

Mowen, John C., \& Minor, Michael. (2002). Perilaku Konsumen Edisi 5, Jilid 2. Jakarta: Penerbit Erlangga.

Rao, Purba. (1996). Measuring Consumer Perception Through Factor Analysis. The Asian Manager, February-March, : 28-32.

Schiffman, Leon G., \& Leslie Lazar Kanuk. (2007). Perilaku Konsumen. Jakarta: Indeks.

Schiffman, Leon G. Dan Leslie Lazar Kanuk. (2010). Consumer Behavior. 10th ed. New Jersey: Pearson Prentice Hall.

Sugiyono. (2005). Statistika untuk Penelitian. Bandung: CV Alfabeta.

Yaufi, Andriyano. (2016). Pengaruh Persepsi Kemudahan, Persepsi Kebermanfaatan, Persepsi Risiko Dan Kepercayaan Terhadap Minat Menggunakan Rekening Ponsel (Studi Kasus

Pada Nasabah Cimb Niaga Daerah Istimewa Yogyakarta).

http://www.apjii.or.id diakses 12 januari 2017

https://id.techinasia.com/ diakses 15 februari 2017

https://cnnindonesia.com/ diakes 30 maret 2017

https://play.google.com/store/apps/details diakses 1 Juni 2017 